\title{
Antibiotic activity of marine microorganisms
}

\author{
Roshan B. Baam, Naren M. Gandhi and Yvonne M. Freitas \\ Department of Microbiology, St. Xavier's College, Bombay, India
}

KURZFASSUNG: Antibiotische Aktivität mariner Mikroorganismen. Aus 41 Seewasserproben verschiedener Herkunft wurden 60 Stämme mariner Bakterien mit antagonistischen Eigenschaften gegenüber Stapbylococcus aureus und Salmonella typhosa isoliert. Die Wirkung verschiedener Nährstoffe auf die Produktion der antimikrobiellen Substanzen wurde untersudht.

\section{INTRODUCTION}

The antagonistic interrelationships among microorganisms have attracted attention since the dawn of bacteriology. The antagonists which are able to combat and destroy disease producing microbes are found to inhabit, in addition to the soil, various other natural substrates. Although, however, the soil organisms have been greatly exploited for their antibiotics, the skein of complicating factors which influence the destruction of terrestrial organisms in marine environments has yet to be fully unravelled.

There are innumerable reports on the bactericidal effects of sea water on the terrigenous microflora (BOyCE \& HARdMAN 1896, KLEIN 1905, Korinek 1927, Trawinski 1929, ZoBell \& Anderson 1936, Carpenter, Setter \& Weinberg 1938, Richou, Neant \& Richou 1955, Pramer, Carlucci \& Scarpino 1963) but ZoBell \& Feltham (1936) were among the first to make specific mention of the possible presence of toxic substances in sea water. In 1952 DE BALSAC, BERTozzr \& GAUdiN observed that the bactericidal principle in sea water was independent of salinity, was thermolabile and persisted after passage through a Chamberland filter.

DE GIAXA (1889) was probably the first to report the existence in the sea, of bacteria antagonistic to anthrax bacilli and Vibrio comma. In 1947, Rosenfeld \& ZoBeli carried out a detailed study on the antibiotic producing marine microorganisms. They found that most antibiotic-producing bacteria belonged to the genera Bacillus and Micrococcus. Although they did not attempt an isolation of specific antibiotics produced by marine bacteria, it was evident from their work that various species of microorganisms indigenous to the sea elaborate antimicrobial substances, and they even suggested that the sea may represent a reservoir of microbial antagonists of possible importance. Further work along similar lines was carried out by KETCHUM, Vaccaro et al. (1950), Ketchum, Carey \& Briggs (1952) and others. 
Table 1

Sea water samples screened for antibiotic producers

\begin{tabular}{|c|c|c|c|}
\hline Sample No. & Location & $\begin{array}{l}\text { Temperature } \\
\text { in } 0^{\circ} \mathrm{C}\end{array}$ & $\begin{array}{l}\text { No. of antibiotic } \\
\text { producers isolated }\end{array}$ \\
\hline 1 & Walkeshwar (near shore) & 28.0 & 1 \\
\hline 2 & Marine Drive (near shore) & 28.0 & - \\
\hline 3 & Marine Drive (near shore) & 28.0 & 1 \\
\hline 4 & Walkeshwar (near shore) & 28.0 & - \\
\hline 5 & Marine Drive (near shore) & 28.0 & - \\
\hline 6 & Walkeshwar (near shore) & 28.0 & - \\
\hline 7 & Marine Drive (near shore) & 28.0 & - \\
\hline$* 8$ & Approx. 10 miles off shore & - & - \\
\hline$* 9$ & Approx. 10 miles off shore & - & 14 \\
\hline$* 10$ & Approx. 10 miles off shore & - & 5 \\
\hline 11 & $18^{\circ} 48^{\prime} \mathrm{N}-72^{\circ} 40^{\prime} \mathrm{E}$ & 28.8 & - \\
\hline 12 & $18^{0} 52^{\prime} \mathrm{N}-72^{0} 42^{\prime} \mathrm{E}$ & 28.5 & 3 \\
\hline 13 & $18^{0} 49^{\prime} \mathrm{N}-72^{\circ} 40^{\prime} \mathrm{E}$ & 28.0 & 5 \\
\hline 14 & $18^{0} 51^{\prime} \mathrm{N}-72^{0} 30^{\prime} \mathrm{E}$ & 28.0 & 2 \\
\hline 15 & $18^{0} 51^{\prime} \mathrm{N}-72^{0} 42^{\prime} \mathrm{E}$ & 28.0 & - \\
\hline 16 & $18^{0} 56^{\prime} \mathrm{N}-72^{0} 36^{\prime} \mathrm{E}$ & 28.0 & - \\
\hline 17 & $18^{0} 56^{\prime} \mathrm{N}-72^{\circ} 85^{\prime} \mathrm{E}$ & 27.0 & - \\
\hline 18 & $18^{0} 50^{\prime} \mathrm{N}-72^{\circ} 82^{\prime} \mathrm{E}$ & 26.2 & - \\
\hline 19 & $18^{0} 50^{\prime} \mathrm{N}-72^{\circ} 38^{r} \mathrm{E}$ & 26.2 & 3 \\
\hline$\approx 20$ & Approx. 10 miles off shore & 26.2 & - \\
\hline$\approx 21$ & Approx. 10 miles off shore & 26.2 & - \\
\hline$\approx 22$ & Approx. 10 miles off shore & 27.2 & - \\
\hline$\approx 23$ & Approx. 10 miles off shore & 31.0 & - \\
\hline$\because 24$ & Approx. 10 miles off shore & 30.5 & 5 \\
\hline$\because 25$ & Approx. 10 miles off shore & 27.3 & - \\
\hline 26 & $18^{0} 52^{\prime} \mathrm{N}-72^{0} 36^{\prime} \mathrm{E}$ & 27.5 & 3 \\
\hline 27 & $18^{\circ} 50^{\prime} \mathrm{N}-72^{\circ} 43^{\prime} \overline{\mathrm{E}}$ & 27.4 & 4 \\
\hline 28 & $18^{0} 50^{\prime} \mathrm{N}-72^{\circ} 38^{\prime} \mathrm{E}$ & 27.3 & - \\
\hline 29 & $18^{0} 50^{\prime} \mathrm{N}-72^{0} 38^{\prime} \mathrm{E}$ & 27.3 & 7 \\
\hline 30 & $18^{\circ} 51^{\prime} \mathrm{N}-72^{\circ} 40^{\prime} \mathrm{E}$ & 27.5 & - \\
\hline 31 & $18^{\circ} 50^{\circ} \mathrm{N}-72^{\circ} 40^{\prime} \mathrm{E}$ & 29.1 & - \\
\hline 32 & $18^{0} 00 \mathrm{~N}-72^{0} 00 \mathrm{E}$ & 30.5 & - \\
\hline 33 & $18^{\circ} 00 \mathrm{~N}-72^{\circ} 00 \mathrm{E}$ & 30.5 & - \\
\hline$\because 34$ & Approx. 10 miles off shore & 30.5 & - \\
\hline 35 & $18^{0} 00 \mathrm{~N}-72^{\circ} 00 \mathrm{E}$ & 30.5 & 7 \\
\hline 36 & $18^{0} 51^{\prime} \mathrm{N}-72^{\circ} 41^{\prime} \mathrm{E}$ & 27.3 & - \\
\hline 37 & $18^{0} 52^{\prime} \mathrm{N}-72^{0} 43^{\prime} \mathrm{E}$ & 27.3 & - \\
\hline 38 & $18^{0} 51^{\prime} \mathrm{N}-72^{\circ} 43^{\prime} \mathrm{E}$ & 30.5 & - \\
\hline 39 & $18^{0} 43^{2} \mathrm{~N}-72^{0} 25^{\prime} \mathrm{E}$ & 27.3 & - \\
\hline 40 & $18^{\circ} 42^{\prime} \mathrm{N}-72^{\circ} 25^{\prime} \mathrm{E}$ & 27.3 & - \\
\hline 41 & $18^{\circ} 52^{\prime} \mathrm{N}-72^{\circ} 45^{\prime} \mathrm{E}$ & 30.5 & - \\
\hline
\end{tabular}

\section{MATERIALS AND METHODS}

Sea water samples were collected from different locations between $18^{0} 00^{\prime} \mathrm{N}-$ $72^{\circ} 00^{\prime} \mathrm{E}$ and $18^{\circ} 52^{\prime} \mathrm{N}-72^{\circ} 85^{\prime} \mathrm{E}$ in previously sterilized glass-stoppered bottles following the method adopted by workers like JoHnstone (1892), HEYDENREICH (1899), Аввотт (1921), Whipple (1927) and ZiLrig (1929). 
For the isolation of the antagonistic bacteria from the sea water sample, the "double layer" method of MCLeon \& GovenLoch (1921), slightly modified by CuRRAVALA (1960) was adopted. The seed layer was superimposed directly on the sea water dilution plate, and the sterile second layer of agar used in the original method was omitted. ZoBeLL's medium 2216 (1941) was used throughout the isolation procedures. The test organisms employed were Staphylococcus aurews F.D.A.209 and Salmonella typhosa str. Ty. 2, the medium being WiLkINs agar (1949). For the isolation of marine actinomycetes, CZAPEK's medium (HENRICI 1947) with $3 \%$ sodium chloride was utilized. The bacterial isolates were maintained on ROSENFELD \& ZoBELL's medium (1947) and the streptomycal on EMERsoN's agar (1917).

A summary of the data regarding the isolation of the sea water samples and the number of active isolates obtained has been presented in Table 1 .

\section{MEDIA STUDIES}

It is a well recognised fact that antibiotic production is altered both qualitatively and quantitatively by the nature of the culture medium. JOHNSTONE \& WAKSMAN (1947), Dulaney \& Perlman (1948), Woodruff \& Ruger (1948), Waksman (1953), Perlman \& O'Brien (1955), Perlman (1956) and Katz, Pienta \& Sivak (1958) have all laid stress on antibiotic production as intimately related to the nutrition of the streptomycetes.

Consequently, a study of the antibiotic production by the isolates was undertaken in various media. Eleven different media were selected for this purpose, starting with the most common liquid medium, Nutrient Broth. Media containing organic supplements and media prepared with indigenous raw materials were examined under optimal conditions of cultivation. All the media selected were incorporated with $3 \%$ sodium chloride.

The media selected were:

(1) Nutrient Broth, (2) Potato Dextrose Broth (ARriagada et al. 1949), (3) Medium of Johnson et al. (1949), (4) Medium of Gausse (1946), (5) Medium of Appleby et al. (1947), (6) Medium of Waksman \& LeChevalier (1949), (7) Medium of Gottlieb et al. (1948), (8) Medium of Gilliver (1949), (9) Glucose Soyabean Beef Medium (Curravala 1960), (10) Groundnut Oilcake Medium (Curravala 1960), (11) Medium of Rosenfeld \& ZoBell (1947). The experiments were conducted in $50 \mathrm{ml}$ amounts of the medium in $250 \mathrm{ml}$ Ehrlenmeyer flasks to obtain a wide shallow layer of growth under stationary conditions. This method (depth of medium $11 \mathrm{~mm}$ ) has been found to provide suitable conditions of growth during studies on different media for antibiotic production by Lewis, Dimick \& Feustel (1945) and SEN \& NANDI (1956). After optimal growth had occurred, $2 \mathrm{ml}$ of the broth were transferred from each flask into sterile test tubes. These were treated with $1 \mathrm{ml}$ of diethyl ether for 1 hour, the ether was then evaporated, the final traces being removed at 45 to $50^{\circ} \mathrm{C}$ in a water bath. The final residue was assayed for antibacterial activity by the "Agar Cup" method of assay (Tables 2 and 3 ).

A tentative indentification of the active isolates was attempted on the basis of 
their morphological and cultural characteristics on various media according to standard procedures (Breed, MurRay \& SMITH 1957, ZoBell \& Upham 1944).

Table 2

Antibiotic activity of marine isolates in various media against Stapbylococcus aureus

\begin{tabular}{|c|c|c|c|c|c|}
\hline \multirow{2}{*}{ Medium } & \multicolumn{3}{|c|}{$\begin{array}{l}\text { Zones of inhibition } \\
\text { in } \mathrm{mm}\end{array}$} & \multirow{2}{*}{$\begin{array}{c}\text { No. of } \\
\text { partially } \\
\text { t ve zones }\end{array}$} & \multirow{2}{*}{$\begin{array}{l}\text { No. of } \\
\text { completly } \\
\text { + ve zones }\end{array}$} \\
\hline & & $10-20$ & $20-30$ & & \\
\hline 1 Nutrient Broth & 56 & 4 & - & 4 & - \\
\hline 2 Potato Dextrose Broth & 50 & 4 & 6 & 1 & 9 \\
\hline 3 Medium of Johnson et al. & 59 & 1 & - & - & - \\
\hline 4 Medium of Gausse & 27 & 33 & - & 33 & - \\
\hline 5 Medium of Aprlebey et al. & 43 & 17 & $\ldots$ & 13 & 4 \\
\hline 6 Medium of Waksman \& LEChevalier & 50 & 10 & - & 2 & 8 \\
\hline 7 Medium of Gottuies et al. & 52 & 2 & 6 & 1 & 7 \\
\hline 8 Medium of GILLIVER & 51 & 9 & - & 3 & 6 \\
\hline 9 Glucose Soya Bean Beef Medium & 49 & 11 & - & 2 & 9 \\
\hline 10 Groundnut Oil Cake Medium & 40 & 7 & 13 & 4 & 16 \\
\hline 11 Rosenfeld \& ZoBell's Medium & 54 & 5 & 1 & 2 & 4 \\
\hline
\end{tabular}

Table 3

Antibiotic activity of the marine isolates in various media against Salmonella typhosa

\begin{tabular}{|c|c|c|c|c|c|}
\hline \multirow{2}{*}{ Medium } & \multicolumn{3}{|c|}{$\begin{array}{l}\text { Zones of inhibition } \\
\text { in } \mathrm{mm}\end{array}$} & \multirow{2}{*}{$\begin{array}{c}\text { No. of } \\
\text { partially } \\
+ \text { ve zones }\end{array}$} & \multirow{2}{*}{$\begin{array}{l}\text { No. of } \\
\text { completly } \\
\text { t ve zones }\end{array}$} \\
\hline & 0 & $10-20$ & $20-30$ & & \\
\hline 1 Nutrient Broth & 59 & 1 & - & - & 1 \\
\hline 2 Potato Dextrose Broth & 58 & 2 & - & 2 & - \\
\hline 3 Medium of JoHnson et al. & 59 & 1 & - & - & 1 \\
\hline 4 Medium of Gausse & 9 & 15 & 36 & - & 51 \\
\hline 5 Medium of APrLEBEY et al. & 39 & 21 & - & 17 & 4 \\
\hline 6 Medium of Waksman \& LeChevalier & 29 & 28 & 3 & - & 31 \\
\hline 7 Medium of GotTLIEB et al. & 58 & 2 & - & - & 2 \\
\hline 8 Medium of GrLLIVER & 29 & 24 & 7 & 12 & 19 \\
\hline 9 Glucose Soya Bean Beef Medium & 45 & 15 & - & 6 & 9 \\
\hline 10 Groundnut Oil Cake Medium & 22 & 32 & 6 & 24 & 14 \\
\hline 11 ROSENFELD \& ZOBELL'S Medium & 59 & 1 & - & - & 1 \\
\hline
\end{tabular}

\section{RESULTS AND DISCUSSION}

The isolation procedures resulted in the isolation from 41 sea water samples, of 60 cultures elaborating antibiotic principles against one or both the test organisms. It was observed that 45 of the antagonists isolated from the different sea water samples were aerobic spore-forming bacilli. Eleven belonged to the group of gram-positive cocci, 2 others were gram-negative bacilli and 2 of the isolates belonged to the genus Streptomyces. 
All the media selected were found to promote good growth, pellicle formation was very common, and thick, heavy pellicles with a wrinkled appearance were often encountered. It was, however, noted that the amount of growth of an isolate in a particular medium had no correlation with the amount of antibiotic produced.

Of all the media examined, the medium found consistently good for antibiotic production was GAusse's medium. Antibiotic production by most of the isolates was stimulated in this medium. An important observation was the fact that 51 of the 60 isolates showed high antibiotic activity against Salmonella typhosa, the zones of inhibition obtained being cidal in nature, while 33 of the 60 isolates which were active against Stapbylococcus aureus gave zones of partial inhibition. The zones of complete inhibition ranged from $14 \mathrm{~mm}$ to $28 \mathrm{~mm}, 40$ isolates giving zones of $20 \mathrm{~mm}$ and above. Even where the zones of inhibition were static in nature, as against Stapbylococcus aureus, they were usually large and measured on an average, $18 \mathrm{~mm}$ to $19 \mathrm{~mm}$.

The groundnut oil cake medium was found to be the next best, 14 isolates giving complete zones of inhibition and 24 giving partial zones of inhibition against Salmonella typhosa, ranging from $19 \mathrm{~mm}$ to $27 \mathrm{~mm}$ in the former case and $14 \mathrm{~mm}$ to $17 \mathrm{~mm}$ in the latter case. Sixteen isolates showed cidal activity against Staphylococcus aureus, and 4 isolates showed static inhibition. Other media which stimulated antibiotic activity were the alvein production medium of GILLIVER, WAKSMAN \& LECHEVALIER's medium for neomycin, Glucose-Soyabean-Beef Broth and the Corn Steep Medium of GotTLIEB et al. for chloramphenicol.

The medium of APPLEBY et al. was not found suitable for antibiotic production by marine organisms. It was noted that in most of the cases, only zones of static inhibition were obtained. Similar results were obtained with Potato-Dextrose Broth ROSENFELD \& ZoBELL's medium also gave very disappointing results while Nutrient Broth proved to be the poorest medium for the stimulation of antibiotic principles.

The constituents which occurred constantly in the media supporting good antibiotic activity were glucose and salts, such as sodium nitrate and magnesium sulphate, with additional factors such as tryptone and oil cake.

Thus, depending upon the nutritional environments, the various marine bacteria isolated were able to elaborate antimicrobial principles against both the test organisms used.

\section{SUMMARY}

1. 41 sea water samples vollected between $18^{\circ} 00^{\prime} \mathrm{N}-72^{\circ} 00^{\prime} \mathrm{E}$ and $18^{\circ} 52^{\prime} \mathrm{N}-72^{\circ} 85^{\prime} \mathrm{E}$ were screened for marine bacteria possessing antagonistic properties against Staphylococcus aureus and Salmonella typhosa.

2. Of 60 cultures elaborating antibiotic principles, a majority (45) were aerobic spore forming bacilli; the rest included gram-positive cocci (11), gram-negative bacilli (2) and streptomycetes (2).

3. The majority of the isolates showed higher activity against the gram-negative test organism.

4. Eleven different media were used to observe the effect of nutrients on the production of antibiotic substances. 


\section{LITERATURE CITED}

Aввотт, A. C., 1921. The principles of bacteriology. 10th ed., Lea \& Febiger, New York, $686 \mathrm{pp}$.

Appleby, J. C., Knowles, E., Pearson, J. \& White, T., 1947. J. gen. Microbiol. 1, 137.

Arriagada, A., Savage, M. C., Abraham, E. P., Heatley, N. G. \& Sharp, A. E., 1949. Ayfivin: An antibiotic from Bacillus licheniformis: Production in potato-dextrose medium. Br. J. exp. Path. 30, 425-427.

Balsac, H. H. de, Bertozzi \& Gaudin, 1952. Techq. sanit. munic. 47, 223. (Cited by GreenBERG, A. E., 1956.)

Boyce, R. W. \& Hardman, N. A., 1896. Rep. Br. Ass. Adomt Sci. 65, 723.

Breed, R. S., Murray, E. G. D. \& SMith, N. R., 1957. Bergey's manual of determinative bacteriology. 7 th ed., Baillère, Tindall \& Cox, London, $1094 \mathrm{pp}$.

Carpenter, L. V., Setter, L. R. \& Weinberg, M., 1958. Chloramine treatment of sea water. Am. J. publ. Hlth 28, 929-934.

Curravala, B. D., 1960. Antibiotic production by aerobic spore-forming bacilli. Thesis, Univ. of Bombay.

Dulaney Eugene, L., 1948. Observations on Streptomyces griseus. J. Bact. 56, 305-313.

Emerson, P., 1917. Are all soil bacteria and streptothrices that develop on dextrose agar azofiers? Soil Sci. 3, 417-421.

Gausse, G. F., 1946. Colistatin: a new antibiotic substance with chemotherapeutic activity. Science, N. Y. 104, 289-291.

GiAXA, DE, 1889. Uber das Verhalten einiger pathogener Mikroorganismen in Meerwasser. Z. Hyg. InfektKrankh. 6, 162-225.

Grlurver, K., 1949. The antibiotic properties of some species of aerobic spore forming bacilli. Br. J. exp. Path. 30, 214-220.

Gottlieb, D., Bhattacharrya, P. K., Anderson, H. W. \& Carter, H. E., 1948. Some properties of an antibiotic obtained from a species of streptomyces. J. Bact. 55, 409-417.

Greenberg, A. E., 1956. Survival of enteric organisms in sea water. Publ. Hlth Rep., Wash. 71, 77-86.

Heydenreich, L., 1899. Einige Neuerungen in der bacteriologischen Technik. Z. wiss. Mikrosk. $16,145-179$.

Henricr, A. T., 1947. Molds, yeasts and actinomycetes. 2nd ed. Wiley \& Sons, London, 409 pp.

Jornson, C. W., West, H. W., Jones, H. L. \& Long, C. J., 1949. Biocerin: an antibiotic produced by Bacillus cereus. J. Bact. 57, 63-66.

JoHNSTONE, W., 1892. On the collection of samples of water for bacteriological analysis. Can. Rec. Sci. 5, 19-28.

Johnstone, D. B. \& Waxsman, S. A., 1948. The production of streptomycin by Streptomyces bikiniensis. J. Bact. 55, 317-326.

Katz, E., Pienta, P. \& Sivak, A., 1958. The role of nutrition in the synthesis of actinomycin. Appl. Microbiol. 6, 236-241.

Ketchum Bostwick, H., Carey, C. L. \& Briggs, M., 1949. (Cited by Greenberg, A. E., 1956.)

- Ayers, J. C. \& Vaccaro, R. F., 1952. Processes contributing to the decrease of coliform bacteria in a tidal estuary. Ecology 33, 247-258.

Klein, E., 1905. (Cited by Greenberg, A. E., 1956.)

Korinex, J., 1927. Ein Beitrag zur Mikrobiologie des Meeres. (Cited by ZoBell, C. E., 1946.)

Lewis, J. C., Dimick, K. P. \& Feustel, I. C., 1945. Production of tyrothricin in cultures of Bacillus brevis. Ind. Engng Chem. analyt. Edn 37, 996-1004.

MCLEOD, J. W. \& Govenlock, P., 1921. The production of bacteriocidins by microorganisms. Lancet 1, 900-903.

PERLMAN, D., 1956. J. Bact. 72, 214.

- O'Brien, E., Bayan, A. D. \& Greenfield, R. B., Jr., 1955. Antibiotic and vitamin B12 production by a steroid oxidizing actinomycete. J. Bact. 69, 347-352.

Pramer, D., Carlucci, A. F. \& Scarpino, P. V., 1962. The bactericidal action of sea water. 
In: Symposium on marine microbiology. Ed. by C. H. Oppenheimer. C. C. Thomas, Springfield, Ill.

Richou, R., NeAnt, M. \& Richou, H., 1955. Sur le pouvoir bactericide de l'eau de mer à l'égard du staphylocoque. Revue Immunol. Thér. antimicrob. 19, 64-68. In: Biol. Abstr. 30, No 1961, 1956.

Rosenfeid, W. D. \& ZoBeLL, C. E., 1947. Antibiotic production by marine microorganisms. J. Bact. 54, 393-398.

Sen, G. P. \& Nand, P. N., 1956. Antibiotic symposium held at Hindustan Antibiotics, Pvt. Ltd., 1960.

Trawinski, A., 1929. Etudes sur la vitalité des bacilles pathogènes du groupe Coli-typhique dans l'eau de mer. Bull. Inst. Océanogr. Monaco 542,1-3.

Vaccaro, R. F., Briggs, M. P., Carey, C. L. \& Ketchum, B. D., 1950. Vitality of Escherichia coli in sea water. Am. J. publ. Hlth. 40, 1257-1266.

Waksman, S. A., 1953. Neomycin. Rutgers Univ. pr., New Brunswick, N. J.

- \& LeChevaliek, H. A., 1949. Neomycin, a new antibiotic active against streptomycin resistant bacteria including tuberculosis organisms. Science 109, 305-307.

Whipple, G. C., 1927. The microscopy of drinking water. Wiley \& Sons, N. Y.

WOODRUFF, H. B. \& RUGER, M., 1948. Studies on the physiology of a streptomycin strain of Streptomyces griseus on proline medium. J. Bact. 56, 315-322.

ZILLIG, A. M., 1929. Bacteriological studies of Lake Erie. Bull. Buffalo Soc, nat. Sci. 14, 51-58.

ZoBelL, C. E., 1941. Studies on marine bacteria. 1. The cultural requirement of heterotrophic aerobes. J. Mar. Res. 4, 42-75.

- 1946. Marine microbiology. Chronica Botanica Co., Waltham, Mass., 240 pp.

- \& Anderson, D. Q., 1936. Biol. Bull. mar. biol. Lab., Woods Hole 71, 324-342.

- \& Feltham, C. B., 1936. Are there specific marine bacteria? Proc. 5th Pacif Sci. Congr. 3, 2097-2100.

- \& Upham, H. C., 1944. A list of marine bacteria including descriptions of sixty new species. Bull. Scripps Inst. Oceanogr, tech. Ser. 5, 239-292. 